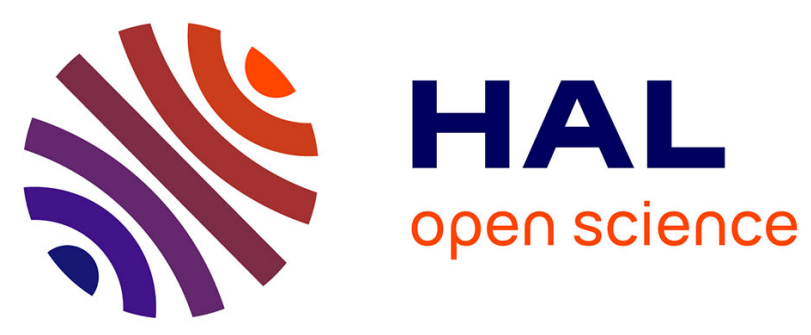

\title{
Managing Enterprise Resource System (ERP) and Balanced Scorecard (BSC) in Food Industry in Brazil - Food and Beverage Products: A Multiple Case Study
}

Celso Affonso Couto, Marcos De Oliveira Morais, Antonio Sergio Brejão, Oduvaldo Vendrametto, Pedro Costa Neto

\section{To cite this version:}

Celso Affonso Couto, Marcos De Oliveira Morais, Antonio Sergio Brejão, Oduvaldo Vendrametto, Pedro Costa Neto. Managing Enterprise Resource System (ERP) and Balanced Scorecard (BSC) in Food Industry in Brazil - Food and Beverage Products: A Multiple Case Study. IFIP International Conference on Advances in Production Management Systems (APMS), Sep 2017, Hamburg, Germany. pp.99-104, 10.1007/978-3-319-66926-7_12 . hal-01707291

\author{
HAL Id: hal-01707291 \\ https://hal.inria.fr/hal-01707291
}

Submitted on 12 Feb 2018

HAL is a multi-disciplinary open access archive for the deposit and dissemination of scientific research documents, whether they are published or not. The documents may come from teaching and research institutions in France or abroad, or from public or private research centers.
L'archive ouverte pluridisciplinaire HAL, est destinée au dépôt et à la diffusion de documents scientifiques de niveau recherche, publiés ou non, émanant des établissements d'enseignement et de recherche français ou étrangers, des laboratoires publics ou privés. 


\title{
Managing Enterprise Resource System (ERP) and Balanced Scorecard (BSC) in Food Industry in Brazil - food and beverage products -: A Multiple Case Study
}

\author{
Celso Affonso Couto, Marcos de Oliveira Morais,Antonio Sergio Brejão, Dr. \\ Oduvaldo Vendrametto and Dr. Pedro Luiz de Oliveira Costa Neto \\ Graduate Programm in Production Engineering, Paulista University - UNIP, Street Dr. Bacelar, \\ 1212, São Paulo, SP 04026-000, Brazil \\ celsoacouto@hotmail.com
}

\begin{abstract}
This study aims to verify, analyze, and describe the importance of managing the Enterprise Resource Planning-ERP information system and the Balanced Scorecard-BSC strategic management system in the food industry in Brazil. The synergies, benefits, problems, and difficulties between them that can influence the implementation of the strategy in the organization to improve the results are analyzed.The present study focuses on the relationship between ERP and BSC, as well as the particularities of each that can influence the efficient management of the organization. The study was based on a multiple case study in five food industries located in Brazil. The theoretical framework was based on topics related to production and operations, strategy, organizational systems, integrated management system (ERP), strategic management system (BSC) and performance indicators. The conclusion of this study highlights the importance of each of these systems, as well as the synergies, benefits, problems, and difficulties among them in the execution of the strategy in organizations.
\end{abstract}

Keywords: Strategy. Systems. Information Technology. ERP. BSC.

\section{Introduction}

The Brazilian food industry (food and beverage products) has faced decades of problems with high tax burden, high raw material costs, high logistical costs and fierce market competition. With this, Brazil loses its competitive power about the quality and prices practiced by other countries [1].

According to the Brazilian Food Industry Association (ABIA) [1] the food industry, which includes the production of food and beverage products, represented in 2016 the amount corresponding to 12\% of the Brazilian GDP. The results could be better if the strategy planned by the companies could

adfa, p. 1, 2011

(C) Springer-Verlag Berlin Heidelberg 2011 
be translated into actions and performance indicators that could involve a larger number of employees [1].

Amongst the main challenges for the food and beverage industry that require extensive attention and continuous process improvement, it is possible to mention: stock control and storage, product's distribution, quality control and compliance with specific standards. Given the sector's challenges, it is worth emphasizing that the use of an integrated information system (ERP) and a strategic management system (BSC) is a fundamental tool for strategic, tactical and operational management [2]. According to [13], for the BSC use in the Strategic Management System to be effective, it needs to be integrated with an ERP - Information Management System.

Constant monitoring of competitive pressures over the years has prompted a series of investigations, not only in the area of integrated information systems but also in the strategic management systems segment of organizations [3]. It is interesting to note that according to [1], 96\% the food industries have been working with ERP and BSC systems for more than ten years in getting their business.

This study aimed to analyze the ERP system and the BSC system in the food industry for identifying:

- Whether there is integration between ERP and BSC and the benefits that the ERP offers to the BSC;

- The problems and difficulties of the ERP to meet the BSC; and

- The consequences for the organization of the problems and challenges generated by the ERP to meet the BSC.

\section{Literature Review}

A synthesis of the theory to the support of the study is provided, with the presentation of a brief history of management of production systems and operations, strategy, organizational systems, integrated management systems - ERP's, performance indicators and BSC - strategic management system.

The topics were analyzed as the theoretical basis for the understanding of each of the theories, the relations between them and for the purpose of the research that is to verify the alignment (synergies/difficulties) between the BSC and ERP in the execution of the strategy in the organizations.

The authors of the BSC - strategy management system [11] conceptualize strategy as the choice of market segments and customers that business units intend to serve [4]. 
The Information Technology (IT) is considered as one of the corporate resources that support strategy at all levels of the organization, giving elements to the business in gaining competitive advantage [5]. The importance of IT grows at all levels of decision-making, IT improves the communication, integration, and exchange of information among all areas of the organization, enabling at all levels knowledge and operationalization of the strategy defined by the organization [6].The quality of every decision depends greatly on the quality of information and synergies among the systems deployed in the organization [7].The evolution of management information systems has brought advances in production planning and control systems, with significant cost reductions and improved quality and customer satisfaction [8].

The choice of an ERP affects the stakeholders or social groups that participated in the market. ERP is the choice to determinate a critical point to ensure the obtaining of transparent and reliable information that supports the strategy and decision making in the organization. It is necessary for the information systems strategy to reflect the company's strategy [10].In the case of organizations, the indicators enable the unfolding of the business goals in the organizational structure, ensuring that improvements achieved in each unit will contribute to the overall purposes of the organization [11]. The indicators help the organization to direct its efforts towards the strategy and test the organization's progress [12].

The acceptance and worldwide growth of the use of the BSC methodology are due to the IT areas, which automated the method, thus allowing its application with greater practicality [13]. The BSC methodology is based on four perspectives on the organization's vision and strategy: Financial Perspective, Customer Perspective, Internal Processes Perspective and Innovation and Learning Perspective [14].The benefits considered by scholars and researchers in the implementation of the Kaplan and Norton model are in the alignment of outcome indicators with trend indicators. Those are related to consideration of different interest groups, such as in the analysis and execution of the strategy; the strategy communication; it is focused on actions, and being a flexible management and monitoring tool for strategic planning. 


\section{$3 \quad$ Materials and Methods}

\subsection{The Research}

A preliminary bibliographical survey was carried out to identify the main questions regarding the ERP system (functions, benefits, comments, and statements) and the BSC system (functions, purposes, benefits, and limitations) in current literature. Afterward, 12 pilot companies were visited to identify which companies were willing to participate in the survey. With the support of these companies, there were chosen the main questions that should be included in the questionnaire to satisfy the research objective. The questionnaire had 15 questions, and it was applied to the manager of the financial area, controlling, logistics, production, information technology, human resources, administration, sales and after sales.

The research was carried out in five food industries based in Brazil with the objective of verifying and analyzing the existence of synergies and difficulties between the BSC (Balanced Scorecard) strategic management systems and the ERP (Enterprise Resource Planning), in the execution of the organization's strategy.

\subsection{The Case Study}

Due to the empirical research, we choose the case study method to describe and analyze the integration and synergy between BSC and ERP [15].In a research conducted using the case study method, dual-dimensions should be considered [16]:

- The number of cases that make up the study; and

- The focus attributed to the unit under analysis.

The purpose of the use of multiple cases is to enable the comparison between the ERP system and the BSC system in different companies that use these two management systems.Table 1 presents the characteristics of the food industries researched. 
Table1:Characteristics of Food Industries (food and beverage products) researched in Brazil.

\begin{tabular}{|c|c|c|c|c|c|}
\hline Industries & 1 & 2 & 3 & 4 & 5 \\
\hline $\begin{array}{l}\text { Established } \\
\text { (Year) }\end{array}$ & 1970 & 2009 & 1905 & 1963 & 1921 \\
\hline $\begin{array}{l}\text { Source of } \\
\text { Capital }\end{array}$ & $\begin{array}{l}\text { Brazil and } \\
\text { Nether- } \\
\text { lands }\end{array}$ & Brazil & Holanda & Brazil & Switzerland \\
\hline Branch & $\begin{array}{l}\text { Foods / } \\
\text { Beverage }\end{array}$ & $\begin{array}{l}\text { Foods / } \\
\text { Beverage }\end{array}$ & Foods & Foods & Foods \\
\hline Products & $\begin{array}{l}\text { Foods / } \\
\text { Beverage }\end{array}$ & $\begin{array}{l}\text { Foods / } \\
\text { Beverage }\end{array}$ & Foods & Foods & Foods \\
\hline $\begin{array}{l}\text { Revenues in } \\
\text { Bra- } \\
\text { zil(year2016) }\end{array}$ & US\$ 1.4 bi & US\$ $16.1 \mathrm{bi}$ & US\$ 16.5 bi & US $\$ 2.2 \mathrm{bi}$ & US\$ 1.8 bi \\
\hline $\begin{array}{l}\text { Employe- } \\
\text { es(2016) }\end{array}$ & ca. 5,200 & ca. 105,733 & ca. 17,000 & ca. 6,421 & ca. 21,642 \\
\hline $\begin{array}{l}\text { Domestic } \\
\text { Market }\end{array}$ & $\begin{array}{l}\text { In all } \\
\text { Brazil }\end{array}$ & In all Brazil & In all Brazil & In all Brazil & In all Brazil \\
\hline $\begin{array}{l}\text { International } \\
\text { Market }\end{array}$ & $\begin{array}{l}\text { Europe / } \\
\text { USA/ } \\
\text { Asia / } \\
\text { Africa }\end{array}$ & $\begin{array}{l}\text { Europe / } \\
\text { USA / Asia } \\
\text { / Africa }\end{array}$ & $\begin{array}{l}\text { Europe / } \\
\text { USA /Asia } \\
\text { /Africa }\end{array}$ & $\begin{array}{l}\text { Europe / } \\
\text { USA/Asia } \\
\text { /Africa }\end{array}$ & $\begin{array}{l}\text { Europe / } \\
\text { USA } \\
\text { Asia /Africa }\end{array}$ \\
\hline
\end{tabular}

\section{Discussion of the Case Study - Results}

Analyzing the answers of the interviewees, it was possible to state that:

- The main synergies between the BSC and the ERP are in the planning, calculation, monitoring, and dissemination of performance indices together with the speed, quality and reliability of the information;

- Synergy and integration between ERP and BSC brought improvements in production and operations processes, productivity gains, cost savings, improved product and service quality, increased market share and profitability;

- The benefits generated by the integration and synergy between the BSC and the ERP refer to the monitoring and control of the objectives and goals of the industry, timely correction in the decision-making process, the reports made available at any time and improvements in the processes of cost rationalization;

- The difficulty in integrating BSC with ERP is one that could at first be considered predictable: the ERP was not prepared to meet all the 
needs of the BSC; consequently, there was a need for adjustments and improvements with the generation of additional, unplanned costs.

The problems in integration and difficulties between BSC and ERP systems observed in all industries surveyed were:

- The areas that presented the greatest difficulties in this regard were the areas of logistics, production, and sales, while in the financial, accounting and controlling areas, the integration of the BSC was normal;

- However, the greatest difficulty common to all the industries surveyed was the lack of understanding of those involved in the proposal that the BSC system intended to take the organization's strategy to the knowledge and participation of all. The training factor was considered the most vulnerable point in the process and was later used on a larger scale to raise awareness and minimize resistance to change.

\section{$5 \quad$ Final Remarks}

The use of information management systems (ERP) and strategic management (BSC) becomes a significant competitive advantage for the food industries in Brazil, so it is possible to understand why $96 \%$ of the food industries use ERP and BSC in the management of their businesses.

The multiple-case study method discussed in this study showed that the ERP and the BSC, as well as the synergies between them, meet the needs of the management and execution of the strategy in these organizations. Both ERP and BSC systems, integrated, bring benefits in stock control and storage of the raw material and the finished product, avoiding perishable products spoil and cause damages. Both ERP and BSC integrated through synergies, contribute to the control of quality management that is determinant in the food industries, through defined processes and parameterized for each batch produced. These systems make it possible to manage the quality of products purchased and finished, issue reports of non-conformity, batch domain and mainly product traceability.

ERP and BSC, individually, and primarily by their synergies facilitate compliance with the legal standards that certify the release of consumption for the product. These systems issue technical reports, printing of nutritional labels with details of product specification and its components to meet specific legal standards. It is observed that when there are synergies, integration between the ERP and the BSC these companies become more competitive and more profitable. 


\section{References}

1. ABIA - Associação Brasileira das Indústrias de Alimentação. Relatório Anual 2016. São Paulo (2016)

2. Rifkin, J.:The Zero Marginal Cost Society: The Internet of Things, the Collaborative Commons, and the Eclipse of Capitalism. Palgrave MacMillan Trade, New York (2014)

3. Neumann, C.:Gestão de sistemas de produção e operações. Elsevier, Rio de Janeiro( 2013)

4. Kaplan, R. S.; Norton D. P.:The balanced scorecard: measures that drive performance. Harvard Business Review, v. 70, n.1, pp 711-85 (1992)

5. Canepa, P.; Rigoni, E.; Brobeck, A.F.: Práticas de alinhamento estratégico: umestudo exploratório em organizações industriais e de serviços. RAM - Revista de Administração Mackenzie, v.9, n.1, pp107-129, (2008)

6. Brobeck, A.F. et al.:Configuração de um processo de seleção, aquisição e implementação de ERP considerando os Grupos Sociais envolvidos. Revista Eletrônica de Sistema de Informação, v.9, n.1, artigo 2 (2010)

7. Robins, S.P.; Coulter, M.: Management. Prentice-Hall, New York (1999)

8. Vollmann,T. E. et al.: Sistemas de planejamento e controle da produção: para o gerenciamento da cadeia de suprimentos. Bookman, Porto Alegre(2006)

9. Brodbeck, A.F. et al.:Configuração de um processo de seleção, aquisição e implementação de ERP considerando os Grupos Sociais envolvidos. Revista Eletrônica de Sistema de Informação, v.9, n.1, artigo 2 (2010)

10. Micheli, P.; Mura, M.: Executing strategy through comprehensive performance measurement systems. International Journal of Operations \& Production Management. Volume 37, Issue 4(2017)

11. Kaplan, R.S.: Conceptual Foundations of the Balanced Scorecard. Handbooks of Management Accounting Research. Elsevier, volume 3, pp 1253-1269 (2009)

12. Kaplan, R. S.; Norton D. P.:The balanced scorecard: measures that drive performance. Harvard Business Review, v. 70, n.1, pp 711-85 (1992)

13. Kaplan, R. S.; Norton D. P.: The Strategy-focused Organization: How balanced Scorecard Companies Thrive in the new business environment. Harvard Business School Press. Boston, Massachusetts (2001)

14. Kaplan, R. S.; Norton D. P.: Translating Strategy into Action. Harvard Business School Press. Boston, Massachusetts (1996)

15. Yin, R. K.: Case study research: design and methods. Sage, Londres (1989)

16. Yin, R. K.: Application of Case Study Research. $3^{\text {rd }}$ ed. Sage, Londres (2012) 